\title{
Pelatihan English Daily Conversation pada Yayasan Darussalam, Depok
}

\author{
Ary Iswanto Wibowo ${ }^{1}$, Jimmi $^{2}$, Cicih Nuraeni $^{3}$, Aprillia $^{4}$ \\ 1,2,3,4 Universitas Bina Sarana Informatika \\ Jalan Kramat Raya No.98 Kwitang Senen Jakarta, Indonesia \\ e-mail: ${ }^{1}$ ary.anb@bsi.ac.id, ${ }^{2}$ jimmi.jmm@bsi.ac.id, ${ }^{3}$ cicih@bsi.ac.id, ${ }^{4}$ aprillia.prl@bsi.ac.id
}

\begin{abstract}
Abstrak
Tujuan dari penelitian ini adalah memberikan pelatihan keahlian kepada masyarakat betapa pentingnya komunikasi berbicara menggunakan Bahasa Inggris. Pelatihan difokuskan pada percakapan Bahasa Inggris sehari-hari yang dilakukan di Yayasan Darussalam, Depok Timur. Metode penelitian yang dipakai dalam riset ini adalah berbasis kualitatif deskriptif dengan tehnik role-play. Data berasal dari peserta pengabdian masyarakat yang berusia antara 13 hingga 17 tahun. Skala pengukuran menggunakan level kemampuan berbicara dari level terendah 1 hingga level tertinggi 6 . Hasil yang didapatkan dari riset ini sebanyak 1 peserta pada level 4, 9 peserta pada level 3, 5 peserta pada level 2, 2 peserta pada level 1 .
\end{abstract}

Kata Kunci: Bahasa Inggris, percakapan, level

\begin{abstract}
The aim of this research is to give practice and knowledge to a community that considerably important to speaking English language. Training was focused on English daily conversation which held on Yayasan Darussalam, East Depok. Methodology research was used by qualitative descriptive research with role-play technique. Data came from all participants of community service who aged from 13- to 17-year-old. Measuring scale used speaking skill level from the lowest level 1 up to the highest level 6. The result from this research were one participant at level 4, 9 participants at level 3, 5 participants at level 2, and 2 participants at level 1.
\end{abstract}

Key Words: English language, conversation, level

\section{Pendahuluan}

Pendidikan merupakan salah satu pondasi tingkat kecerdasan manusia. Oleh karena itu, sebagai pelopor pendidikan maka dalam salah satu upaya mencerdaskan masyarakat, tim pengabdian masyarakat program studi Bahasa Inggris dibawah naungan Universitas Bina Sarana Informatika (UBSI) melaksanakan pengabdian masyarakat di Yayasan Darussalam, Depok Timur. Salah satu kewajiban dosen dalam tri dharma perguruan tinggi yaitu memberikan pendidikan dan pelatihan tepat guna kepada masyarakat. Tujuan dari kegiatan ini adalah tidak lain untuk menjawab persoalan-persoalan yang ada di masyarakat. Permasalahan yang terjadi pada mitra ini adalah kesulitan dalam menggunakan percakapan Bahasa Inggris sehari-hari pada tingkat SMP dan SMA. Oleh karena itu, sebagai profesi yang harus dapat memberikan manfaat kepada orang lain, tim pengabdian masyarakat UBSI menyediakan pelatihan bagi para peserta. Sebagai bahasa asing, Bahasa Inggris menjadi bahasa nomor tiga setelah Bahasa Indonesia dan Bahasa daerah. Hal ini yang menjadi tolak ukur masalah dalam penggunaan percakapan Bahasa Inggris.

This work is licensed under a Creative Commons Attribution-ShareAlike 4.0 International License.

Publikasi oleh LPPM Universitas Bina Sarana Informatika 
Bahasa Inggris bukan merupakan bahasa resmi (official language) di Indonesia, tetapi sebagai bahasa asing. Masyarakat Indonesia selain berbahasa Indonesia, sebagian besar juga menguasai bahasa daerah. Seperti saya sendiri, di samping berbahasa Indonesia saya juga berbahasa Jawa bahkan dalam kehidupan sehari-hari lebih banyak menggunakan bahasa Jawa. Suatu bahasa akan berkembang dengan baik karena dipergunakan dalam kehidupan seharihari. Mahasiswa luar Jogja yang datang ke Yogyakarta sebagian besar tidak memahami bahasa Jawa. Tahun pertama kuliah mungkin menjadi masa-masa tersulit karena mereka akan mendengar dan melihat orang Jogja sering mencampur bahasa Jawa dengan bahasa Indonesia dalam percakapan sehari-hari. Namun, seiring dengan waktu para mahasiswa luar Jogja akan memahami bahasa Jawa dan lambat laun akan bisa berbahasa Jawa dengan lancar karena mereka menjumpai bahasa Jawa dalam kehidupan sehari-hari. Tanpa disadari, mendengarkan bahasa Inggris dalam kehidupan sehari-hari adalah proses pembelajaran suatu bahasa secara alami. Nah, bagaimana dengan bahasa Inggris yang sudah dipelajari di sekolah selama kurang lebih 6 tahun? (Subekti, 2018).

\section{Metode}

Dalam jurnal penelitian ini digunakan metode deskriptif dan disajikan secara kualitatif. Djajsudarma dalam Cenderamata menyatakan bahwa metode kualitatif merupakan prosedur yang menghasilkan data secara deskriptif baik lisan maupun tulis yang berkembang atau ada di masyarakat. Dalam metode ini, data dihasilkan secara deskriptif; maksudnya adalah data-data yang didapat tidak dilihat dari benar dan salah, disajikan apa adanya secara sistematis, factual, dan akurat mengenai data, sifat, serta kaitannya dengan fenomenafenomena, (Cenderamata, R. C. \& Agus, 2019).

Masih di artikel yang sama, Sudaryanto dalam Cenderamata mengemukakan dalam metode simak digunakan teknik dasar yang meliputi teknik sadap, simak libat cakap, simak bebas libat cakap, rekam, dan catat, (Cenderamata, R. C. \& Agus, 2019). Dalam penelitian ini digunakan tehnik rekam dimana setiap peserta pengabdian masyarakat secara sukarela direkam gaya bicaranya dalam Bahasa Inggris kemudian diteliti dimana letak kesalahannya dalam pengucapan. Jumlah peserta yang terlibat dalam penelitian ini sebanyak 17 peserta yang berusia antara 13 hingga 17 tahun.

Materi yang disampaikan kepada peserta tidaklah terlalu sulit sehingga memudahkan peserta dalam mempelajari dan mempraktekkannya, seperti dialog percakapan sehari-hari, greeting, baik formal maupun informal greeting, dan penutup percakapan. Tehnik asesmen atau pengambilan nilai untuk keahlian berbicara menggunakan role-plays. Contoh role-play seperti gambar dibawah ini, dimana sesorang diplomat Inggris bersama istri/suaminya dan anak-anaknya ingin pergi ke Yunani untuk liburan. Mereka mencari seorang asisten untuk menemaninya pergi. 


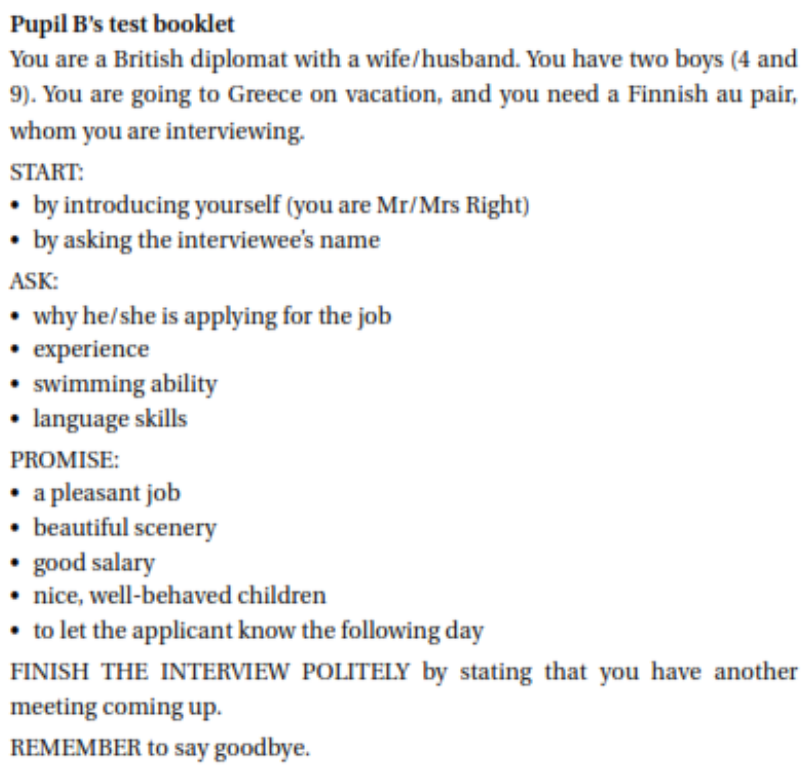

Gambar 1. Contoh bentuk role-play

Pengujian dalam bentuk role-plays juga tidak rumit, ketika penguji meminta peserta untuk memerankan sebagai seorang penumpang di sebuah kereta dengan teman sebangkunya, percakapan di sebuah restoran dan memesan makanan, atau membeli sesuatu di sebuah toko. Tes ini bertujuan untuk mengetahui bagaimana penguji dapat memperoleh data berupa bahasa yang digunakan oleh peserta dan situasi yang dihadapi oleh peserta, (Luoma, 2009).

\section{Hasil dan Pembahasan}

Materi yang disajikan oleh panitia diberikan secara menyenangkan dan membuat nyaman peserta. Hal ini dilakukan karena panitia tidak ingin menimbulkan kesan bahwa belajar Bahasa Inggris itu sulit. Hal ini seperti dikemukakan oleh seorang peneliti sebelumnya yang membuat artikel pada jurnal pengabdian masyarakat bahwa mahasiswa dilatih untuk mampu memperkenalkan diri sendiri, menyatakan waktu, mengeja kata, bertanya, sampai mengetahui struktur kalimat yang sederhana. Selain itu, mahasiswa juga diberikan motivasi untuk mau terus meningkatkan kemampuan Bahasa Inggrisnya karena merupakan suatu kebutuhan dimasa depannya kelak, baik itu berkarir maupun sekolah lanjut, (Permata \& Hadiani, 2018). Adapun peneliti lainnya yang menekankan pada permasalahan percakapan yaitu (Syaifullah \& Andriani, 2021) dimana percakapan Bahasa Inggris digunakan pada pemandu wisata atau tourist guide. 
Menurut (Luoma, 2009) skala penialaian dari hasil percakapan sehari-hari peserta pengabdian masyarakat dibagi menjadi 6 (enam) level kecakapan, yaitu;

Level 1 : dapat bertanya dan menjawab pertanyaan sederhana sehari-hari, dapat menggunakan bentuk kalimat yang sopan, lambat berkomunikasi dan sangat terbatas, sering menggunakan bahasa non-verbal

Level 2 : mencakup rutinitas situasi berbicara yang membutuhkan pertukaran informasi dengan mudah, kecukupan dan kemampuan dari si pembicara terbatas, pelafalan tidak terlalu jelas, ada jeda waktu dalam berbicara

Level 3 : mencakup situasi percakapan yang lebih umum, dapat mengambil inisiatif dalam percakapan sehari-hari, kecepatan berbicara sedikit lambat namun tidak terlihat jeda, pelafalan terlihat cukup jela

Level 4 : komunikasi cukup baik meskpiun kurang menguasai situasi, dapat membedakan bahasa formal dan informal, dapat memberikan opini, dapat berbicara tentang dan menjelaskan pandangan, suara, dan pengalaman

Level 5 : berbicara fasih tanpa membutuhkan ekspresi, dibawakan secara natural, koheren, dan sesuai topik pembicaraaan, dapat memberikan deskripsi yang jelas dan detail, dapat menggunakan idiomatik yang cukup

Level 6 : berbicara fasih seperti native speaker, dapat memberikan arti yang lebih presisi dan bervarasi, menggunakan idiomatic dengan sangat baik, dapat menjelaskan topik yang rumit dan kompleks, mengembangkan perbedaan sudut pandang dan memberikan kesimpulan

Hasil kajian dari pengabdian masyarakat ini dijabarkan dalam bentuk tabel pre-test dan post-test. Terlbih dahulu peserta dilakukan pre-test untuk mengetahui seberapa besar nilai yang bisa didapatkan berdasarkan level diatas.

\begin{tabular}{|c|c|}
\hline Level & Jumlah peserta \\
\hline 6 & 0 \\
\hline 5 & 0 \\
\hline 4 & 0 \\
\hline 3 & 1 \\
\hline 2 & 9 \\
\hline 1 & 7 \\
\hline Total & $\mathbf{1 7}$ \\
\hline
\end{tabular}

Table 1. Hasil Pre-test peserta

Dilihat dari tabel diatas bahwa keahlian Bahasa Inggris yang dimiliki oleh peserta pengabdian masyarakat masih rendah, terbukti dengan di dominasi oleh sebanyak 7 orang peserta yang masih berada pada level 1. Sedangkan pada level 2 sebanyak 9 orang peserta didik. Hanya satu orang yang mendapat nilai tertinggi pada level 3 dari 6 level yang tertera. Kesulitan terbesar yang dialami oleh para peserta adalah pemilihan kosakata dan pengucapan atau pelafalan. Hal ini yang menjadi dasar para peneliti betapa pentingnya kegiatan pengabdian masyarakat ini perlu diadakan. 


\begin{tabular}{|c|c|}
\hline Level & Jumlah peserta \\
\hline 6 & 0 \\
\hline 5 & 0 \\
\hline 4 & 1 \\
\hline 3 & 9 \\
\hline 2 & 5 \\
\hline 1 & 2 \\
\hline Total & $\mathbf{1 7}$ \\
\hline
\end{tabular}

Tabel 2. Hasil post-tes peserta

Dari hasil post-tes yang dilakukan terhadap seluruh peserta dapat dikatakan bahwa hasil pelatihan percakapan Bahasa Inggris sehari-hari cukup baik, hal ini dilihat dari banyaknya peserta yang masuk level 3 sebesar 9 orang. Setelah dilakukan pelatihan terdapat beberapa peserta yang menggunakan percakapan Bahasa Inggris dengan sedikit lambat namun terlihat cukup jelas pelafalannya, sehingga lawan bicaranya mengerti apa yang dikatakan oleh si pembicara.

Sedangkan pada level 2 terdapat 5 peserta yang masih kurang jelas pelafalannya dan ada jeda atau tempo bicara yang agak lama. Hal ini dikarenakan mereka masih memikirkan kosakata apa yang sesuai dengan yang ada dipikiran mereka. Kemampuan penguasaan kosakata ini mengakibatkan para peserta banyak terdiam dengan mengeluarkan bunyi hmmm.... dan sesekali berkata "what is it". Meskipun hasilnya tidak teralu signifikan, namun dengan waktu yang terbatas, penelitian berbasis pengabdian masyarakat ini dirasakan ada manfaat dan berhasil.

\section{Simpulan dan Rekomendasi}

Berdasarkan kegiatan yang telah dilakukan kepada mitra Yayasan Darussalam, Depok Timur dapat disimpulkan bahwa pelatihan percakapan Bahasa Inggris sehari-hari memberikan dampak yang positif dan bermanfaat bagi para peserta. Hal ini ditunjukkan dengan antusiasme para peserta mengikuti kegiatan dari awal hingga selesai. Keterbatasan waktu dalam pelatihan dan tes tidak menyurutkan niat peserta untuk hadir terlibat dalam kegiatan ini.

Kedepannya diharapkan kerja sama antara Tim PM UBSI dan Yayasan Darussalam dapat terus ditingkatkan untuk kemajuan peserta didik. 


\section{Daftar Pustaka}

Cenderamata, R. C. \& Agus, N. S. (2019). Abreviasi dalam Percakapan Sehari-Hari di Media Sosial: Suatu Kajian Morfologi. Kajian Linguistik Dan Sastra, 4(2), 154-163. https://doi.org/http://dx.doi.org/10.23917/kls.v4i2.6284

Luoma, S. (2009). Assessing Speaking. In Cambridge University Press. https://doi.org/10.1017/s0267190500003548

Permata, N. N., \& Hadiani, D. (2018). Pelatihan Bahasa Inggris Dasar Dalam Upaya Peningkatan Kemampuan Mahasiswa Mahasiswa Bidikmisi Polman Bandung. Paper Knowledge . Toward a Media History of Documents, 2(4), 1-5.

Subekti, N. B. (2018). Kesulitan Belajar Bahasa Inggris Tidak Dipergunakan Sehari-hari. 12. https://doi.org/10.31219/osf.io/r4fm3

Syaifullah, \& Andriani, R. (2021). Pelatihan English For Tourist Guide Untuk Himpunan Pramuwisata Indonesia (HPI) Kota Pekanbaru. DINAMISIA Jurnal Pengabdian Kepada Masyarakat - Universitas Lancang Kuning, 5(4). 